\title{
Quality Reliability Service Towards Student Satisfaction
}

\author{
Fajar Isnaeni ${ }^{*}$, Suwignyo Widagdo ${ }^{2}$, Supardi $^{3}$
}

1,2,3 STIE Mandala Jember

\section{A R T I C L E I N F 0}

Article history:

Received 19 August 2019

Received in revised form

16 September 2019

Accepted 15 October 2019

Available online 29

November 2019

Keywords:

Student satisfaction,

Reliability, Service Quality.

\section{A B S T R A C T}

This study aims to examine and analyze the simultaneous effect of service quality on student satisfaction, test and analyze the partial effect of service quality on student satisfaction, test and analyze variables that have a dominant influence on student satisfaction. This research method uses multiple linear regression analysis which is used to determine how much influence the independent (independent) variables, namely Tangible, Reliability, Responsiveness, Assurance, Empathy on the dependent variable is student satisfaction. Research site is at STES Ihya 'Ulumiddin Banyuwangi. The study took a sample of 39 people. While the results of this study can be drawn as follows, the variables Tangible, Reliability, Responsiveness, Assurance and Emphaty simultaneously affect student satisfaction. The partial test of the Reliability variable, Responsiveness, Assurance and Emphaty is positive, but the Tangible variable is negative. Reliability variables are variables that have a dominant and significant influence on student satisfaction.

\footnotetext{
* Corresponding author.

E-mail addresses: fajarisnaini@gmail.com (Fajar Isnaeni)
} 


\section{Introduction}

Customer satisfaction and dissatisfaction are hot topics to be discussed at international, national, industrial and corporate / institutional levels. For companies, this concern arises for two reasons, According to Tjiptono (1996), every company lives from its customers. Therefore, the customer is the only reason for the existence of a company. Thus customer satisfaction must be the top priority of every company. Kotler (2000) in Buchari Alma (2013) revealed that there are five dominant factors or determinants of service quality in a short TERRA, namely: Tangible, Emphaty, Responsiveness, Assurance, In general, satisfaction is a feeling of pleasure or disappointment someone arises because it compares the performance that is perceived by the product (or result) to their expectations. If performance fails to meet expectations, customers will be dissatisfied. If the performance is in accordance with expectations, the customer will be satisfied or happy. Customer assessment of product performance depends on many factors, especially the type of loyalty relationships that customers have with a brand. Consumers often form a more pleasant perception of a product with a brand that they already consider positive. How do buyers shape their expectations? Expectations come from past purchasing experience, advice from friends and colleagues, and information and promises of marketers and competitors. (Kotler, Keller, 2017)

The Islamic Economics College IHYA 'ULUMIDDIN Banyuwangi As a new campus, according to the author, it is considered necessary to be examined, because as a new campus, of course there needs to be a lot of input both Tangibility, Reliability, Responsiveness, Assurance and Emphaty so that the service for students can continue to be improved so that student satisfaction with campus services can be known and eventually becomes an input to campus management in providing services to students. The objectives to be achieved in this study are to examine and analyze the simultaneous effect of service quality on student satisfaction, test and analyze the partial effect of service quality on student satisfaction, test and analyze variables that have a dominant influence on student satisfaction.

This research was conducted at the management of the IHYA 'ULUMIDDIN Banyuwangi Islamic Economics College of Syariah Economics Study Program 2017/2018. The variables of service quality that affect satisfaction uses concepts from Kotler and Keller, (2017): Tangible, Reliability, Responsiveness, Assurance, Emphaty.

Satisfaction in this study is student satisfaction. The concept of satisfaction in this study using the concept of Kotler and Armstrong, (2010) regarding customer satisfaction is the extent to which a product's perceived performance matches a buyers expectation. Satisfaction is the extent to which the performance of a product or service is in accordance with the expectations of buyers.

\section{Methods}

Islamic Economics College IHYA 'ULUMIDDIN Banyuwangi is an addressable campus on Jl. KH. Abdullah Hasbullah 08 Padang Village, Singojuruh Banyuwangi District. Islamic Economics College IHYA 'ULUMIDDIN Banyuwangi in the 2017/2018 Academic Year opens a study program namely Syariah Economy, in the 2017/2018 Academic Year to be the first year of study by getting 50 students, but until the beginning of the 2018/2019 odd semester that survives and continuing the lectures as many as 39 students. While for new students in 2018/2019 there are 52 students.

This study uses descriptive and causal research with a quantitative approach. In this study using saturated or census sampling, where all members of the population are sampled, the population is all students of the STES IHYA 'ULUMIDDIN Banyuwangi Academic Year 2017/2018 as many as 39 students.

The variables that will be analyzed in this study are grouped into two types as follows: (a) Independent Variables: independent variables which are variables that influence or are the cause of the change or the emergence of the dependent variable. (Sugiyono, 2012). Independent variables in this study are Tangible (X1), Reliability (X2), Responsiveness (X3), Assurance (X4), Emphaty (X5) (b) Dependent Variables: The dependent variable in this study is student Satisfaction (Y)

Methods of data collection using (1) questionnaire, (2) interview, (3) observation, for data analysis methods that are used include: (1) Test validity and Reliability (2) Test classic assumptions, including (a) Test for normality (b) Multicollinearity Test (c) Heteroscedasticity Test (3) Multiple linear regression analysis (4) The coefficient of determination. And for the hypothesis testing use the F-Test and the T-Test.

\section{Result and Discussion}

Test the validity of the research instrument was carried out by distributing questionnaires to 39 respondents at the time of the study. From the results of the validity of the research data instrument, the results show that 25 indicators of the variables Tangible (X1), Reliability (X2), Responsiveness (X3), 
Assurance (X4), Emphaty (X5) and Customer Satisfaction (Y) are all valid because of the coefficient value total item correlation ( $r$-count) exceeds 0.30 with a significance level of $p<0.05$. The significance test of instrument validity was also done by comparing the calculated value with r-table for the degree of freedom (df) $=\mathrm{N}-2$ in this pretest. The number of samples (n) was 39 so the magnitude (df) was 33 with a significance level of $5 \%$. then it is known that the r-table value is 0.263 Based on the table above it is proven that all indicators can be proven validity because all $r$-count values are greater than $r$-table.

Reliability test is done to get the level of accuracy of the research data collection tools used. The test results show that the Reliability coefficient value (alpha cronbach) on the student satisfaction variable (Y) is 0.804 , which means that the cronbach alpha value is more than 0.60 . In other words, the Customer Satisfaction variable indicator in this study can be trusted. The research data instrument gave Cronbach alpha value on the Tangible variable (X1) of 0.763, Reliability (X2) of 0.768, Responsiveness (X3) of 0.811, Assurance (X4) of 0.762, Emphaty (X5) of 0.698. This means that all indicators used as variable measurement tools in this study can be trusted because each has a cronbach alpha value of more than 0.60 .

Based on the results of testing the normality of data through SPSS 21.0 software, it can be seen that data spreads around the diagonal line and follows the direction of the diagonal line, so that the regression model meets the assumptions of normality. Multicollinearity test was conducted to test whether the regression model found a correlation between independent variables or not. The test results show that the regression model has a VIF value of each variable less than number 10 . Then it can be concluded that the regression model in this study does not occur the symptoms of multicollinearity. Based on the results of the Heteroscedasticity test results can be seen that the test results illustrate no clear pattern, points spread above and below the number 0 on the $Y$ axis. So that it can be concluded that the regression model does not occur symptoms of heteroscedasticity.

In analyzing the data in this study, the method used by researchers to find out is multiple linear regression analysis. This analysis aims to determine the effect of variables. It means the variables Tangible (X1), Reliability (X2), Responsiveness (X3), Assurance (X4), Emphaty (X5) simultaneously and know the effect of variables. It means variables Tangible (X1), Reliability (X2), Responsiveness (X3), Assurance (X4), Emphaty (X5) partially.

From the results of the regression output using the SPSS 21.0 program which can be seen in Table 1 below.

Table 1. The Regression Output Using The SPSS 21.0

\begin{tabular}{|c|c|c|c|c|c|c|}
\hline & \multicolumn{6}{|c|}{ Coefficients $^{\mathbf{a}}$} \\
\hline & \multirow[b]{2}{*}{ Model } & \multicolumn{2}{|c|}{$\begin{array}{l}\text { Unstandardized } \\
\text { Coefficients }\end{array}$} & $\begin{array}{l}\text { Standardize } \\
\text { d Coefficients } \\
\end{array}$ & \multirow[b]{2}{*}{$\mathrm{t}$} & \multirow[b]{2}{*}{ Sig. } \\
\hline & & $\mathrm{B}$ & Std. Error & Beta & & \\
\hline \multirow[t]{6}{*}{1} & (Constant) & 3.264 & 2.547 & & 1.282 & .209 \\
\hline & TANGIBLES & -.154 & .081 & -.292 & -1.891 & .067 \\
\hline & RELIABILITY & .477 & .182 & .413 & 2.627 & .013 \\
\hline & RESPONSIVENESS & .128 & .183 & .110 & .698 & .490 \\
\hline & ASSURANCE & .381 & .211 & .301 & 1.806 & .080 \\
\hline & EMPHATY & 152 & .211 & .122 & .722 & .476 \\
\hline
\end{tabular}

a. Dependent Variable: CUSTOMER SATISFACTION

$$
Y=3,264+-0,154 X_{1}+0,477 X_{2}+0,128 X_{3}+0,381 X_{4}+0,152 X_{5}+e
$$

The above equation can be explained as follows:

1. Constant (a) of 3.264, meaning that if X1 (Tangible), X2 (Reliability), X3 (Responsiveness), X4 (Assurance), X5 (Emphaty) the value is 0, then the value of student satisfaction is positive.

2. $\mathrm{bx} 1, \mathrm{X} 1$ (Tangible) variable regression coefficient of -0.154 , meaning that if the other independent variables X2 (Reliability), X3 (Responsiveness), X4 (Assurance), X5 (Emphaty) the value does not exist or $=0$ and $\mathrm{X} 1$ (Tangible) increase, student satisfaction is negative.

3. bx2, the regression coefficient of X2 (Reliability) variable is 0.477 , meaning that if the other independent variables X1 (Tangible), X3 (Responsiveness), X4 (Assurance), X5 (Emphaty) the value does not exist or $=0$ and Reliability is increased then satisfaction students will be positive. The coefficient is positive. It means there is a positive relationship between Reliability and student satisfaction. The higher the Reliability, the higher student satisfaction. 
4. bx3, the regression coefficient of X3 variable (Responsiveness) is 0.128 , meaning that if other independent variables X1 (Tangible), X2 (Reliability), X4 (Assurance), X5 (Emphaty) the value does not exist or $=0$ and Responsiveness is increased, then student satisfaction will be positive. The coefficient is positive, meaning there is a positive relationship between Responsiveness and student satisfaction. The higher Responsiveness, student satisfaction increases.

5. bx4, variable regression coefficient X4 (Assurance) of 0.381 means that if other independent variables X1 (Tangible), X2 (Reliability), X3 (Responsiveness), X5 (Emphaty) the value does not exist or $=0$ and Assurance is increased, then satisfaction positive student. The coefficient is positive, meaning there is a positive relationship between Assurance and student satisfaction. The higher the Assurance, the more student satisfaction increases.

6. bx5, the regression coefficient of variable X5 (Emphaty) is 0.152 , meaning that if the other independent variables X1 (Tangible), X2 (Reliability), X3 (Responsiveness), X4 (Assurance) the value does not exist or $=0$ and Emphaty is increased then satisfaction students will be positive, meaning that there is a positive relationship between empathy and student satisfaction. The higher the empathy, the higher student satisfaction.

The value used in this study is the adjusted R2 value because this value can go up and down if one independent variable is added to the tested model. The results of the coefficient of determination can be seen in Table 2 below:

Table 2. Regression Test Results (Coefficient of Determination)

\begin{tabular}{|l|c|r|r|l|}
\hline \multicolumn{9}{|c|}{ Model Summary } \\
\hline Model & & \multicolumn{2}{l|}{$\begin{array}{l}\text { Adjusted R } \\
\text { Square }\end{array}$} & $\begin{array}{l}\text { Std. Error of the } \\
\text { Estimate }\end{array}$ \\
\hline 1 & $\mathrm{R}$ & R Square & .318 & 1.417 \\
\hline
\end{tabular}

a. Predictors: (Constant), EMPHATY, RELIABILITY, TANGIBLES, RESPONSIVENESS, ASSURANCE

b. Dependent Variable: CUSTOMER SATISFACTION

Based on Table 2 above, it can be seen that the adjusted R2 value is 0.318 . This means that the independent variables consisting of variables Tangible (X1), Reliability (X2), Responsiveness (X3), Assurance (X4), Emphaty (X5) can explain the dependent variable in this case consumer satisfaction by $31.8 \%$. while the remaining $68.2 \%$ is influenced by other variables not included in this study.

Simultaneous testing (F-Test) is used to test the significance of the effect jointly between the independent variables on the dependent variable. The testing technique is done by comparing the value of F-count with the value of F-table at the significance level of 0.05 and the level of confidence (level of confidence) of $95 \%$.

Based on the results of testing multiple regression analysis, the F-count value is 4,536 with a significance number ( $\mathrm{P}$ value) of $0,000<0,05$ with a significance level of $95 \%$, while in the $\mathrm{F}$ table is 2,34 . This value indicates that F-count is greater than F-table, then Ha is accepted and Ho is rejected. This means that the variables Tangible (X1), Reliability (X2), Responsiveness (X3), Assurance (X4), Emphaty (X5) have a simultaneous effect on STES IU customer satisfaction.

This T-test aims to determine the magnitude of the partial influence of Tangible (X1), Reliability (X2), Responsiveness (X3), Assurance (X4), Emphaty (X5) variables on the STES IU Customer Satisfaction. Hypothesis testing is done by comparing the calculated value with t-table, if the resulting t-count value is greater than t-table, then the hypothesis is accepted. and vice versa, if the resulting t-count value is smaller than t-table, the hypothesis is rejected. While the presence or absence of significant influence can be seen from the significance value. If the significance value is smaller than 0.05 (confidence level (5\%), the independent variable has a significant effect on the dependent variable. The results of testing multiple regression analysis using the t-test can be seen in Table 3 below.

Table 3

\begin{tabular}{|c|c|c|c|c|c|c|}
\hline \multicolumn{7}{|c|}{ Coefficients $^{a}$} \\
\hline & \multirow[b]{2}{*}{ Model } & $\begin{array}{l}\text { Unstanda } \\
\text { Coefficier }\end{array}$ & $\begin{array}{l}\text { ardized } \\
\text { ats }\end{array}$ & $\begin{array}{l}\text { Standardized } \\
\text { Coefficients }\end{array}$ & \multirow[b]{2}{*}{$\mathrm{t}$} & \multirow[b]{2}{*}{ Sig. } \\
\hline & & $\mathrm{B}$ & Std. Error & Beta & & \\
\hline \multirow[t]{3}{*}{1} & (Constant) & 3.264 & 2.547 & & 1.282 & 209 \\
\hline & TANGIBLES & -.154 & .081 & -.292 & -1.891 & .067 \\
\hline & RELIABILITY & 477 & .182 & .413 & 2.627 & .013 \\
\hline
\end{tabular}




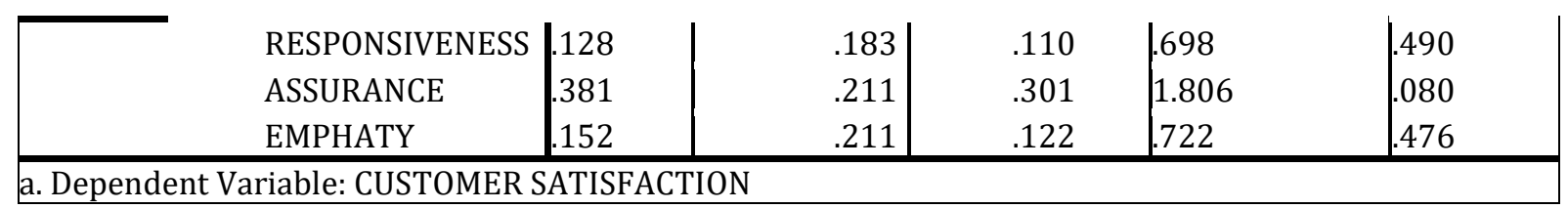

\section{INTERPRETATION}

Based on simultaneous hypothesis testing, it is stated that the variables Tangible, Reliability, Responsiveness, Assurance and empathy affect student satisfaction. This means that the overall service quality possessed by STES can increase student satisfaction.

The first hypothesis states that there is a significant effect of the Tangible variable partially on student satisfaction at STES IU. Based on the results of testing multiple linear regression in Table 3 shows the value of $t$-count of $-1,891$ while at $t$-table of 1,68 (df 95 with a confidence level of 5\%). This means that there is no significant effect of Tangible variables on STES student satisfaction. Negative values indicate the existence of an opposite relationship between Tangible variables and student satisfaction.

The second hypothesis states that there is a significant effect of the Reliability variable partially on student satisfaction at STES IU. Based on the results of testing multiple linear regression in Table 3 shows the value of t-count of 2.627 while at $t$-table of 1.68 (df 95 with a confidence level of 5\%). This means that there is a significant effect of the Reliability variable on the satisfaction of STES IU students. Positive values indicate a unidirectional relationship between Reliability and student satisfaction variables. The magnitude of the effect is 0.477 or $47.7 \%$.

The third hypothesis states that there is a significant effect of the Responsiveness variable. partially towards student satisfaction at STES IU. Based on the results of multiple linear regression testing in Table 3 , the t-count value is 0.698 while at $\mathrm{t}$-table is 1.68 ( $\mathrm{df} 95$ with a confidence level of 5\%). This means that there is no significant effect of the Responsiveness variable on the satisfaction of STES IU students.

The fourth hypothesis states that there is a significant effect of the Assurance variable partially on student satisfaction at STES IU. Based on the results of testing multiple linear regression in Table 3 shows the value of $t$-count of 1.806 while at $t$-table of 1.68 (df 95 with a confidence level of 5\%). Positive values indicate a unidirectional relationship between variable Assurance and student satisfaction. The amount of influence is 0.381 or $38.1 \%$

The fifth hypothesis states that there is an effect of the Emphaty variable partially on student satisfaction at STES IU. Based on the results of testing multiple linear regression in Table 3, the t-count value is 0.722 while at $\mathrm{t}$-table is 1.68 ( $\mathrm{df} 95$ with a confidence level of $5 \%$ ). This means that there is no significant effect of the empathy variable on the satisfaction of STES IU students.

This study states that the most dominant and significant influence is Reliability variable on Student Satisfaction at STES. Based on the results of testing multiple linear regression in Table 3 shows the value of $\mathrm{t}$-count of 2.627 while at $\mathrm{t}$-table of 1.68 ( $\mathrm{df} 95$ with a confidence level of 5\%). This value indicates that the $t$-value is greater than $t$-table. While the significance value is 0.067 greater than 0.05 , thus the first hypothesis is accepted. This means that there is a significant effect of Reliability variable on the satisfaction of STES IU students. Positive values indicate a relationship between Reliability and student satisfaction variables. The amount of influence is 0.318 or $31.8 \%$

\section{Conclusion}

Based on the results of the discussion described in the previous chapter, there are several conclusions that can be drawn as follows: (1) The variables Tangible, Reliability, Responsiveness, Assurance and Emphaty simultaneously influence student satisfaction. This means that the better the quality of services in the 5 variables will increase student satisfaction. (2) Partial testing of Reliability Variables, Responsiveness, Assurance and Emphaty is positive, except the Tangible variable (X1) is negative, this indicates that the variable has a positive value on student satisfaction. Unless the Tangible variable (X1) is negative in other words, the physical evidence currently does not satisfy students. (3) Reliability Variables (X2) are variables that have a dominant and significant effect on student satisfaction. This can be interpreted that the higher the competence of lecturers, teaching materials, friendly lecturers and objective assessment will give satisfaction to students.

The results of this study indicate that the Reliability variable has a significant influence compared to the other variables (Tangible, Responsiveness, Assurance and Emphaty Variables). The survey results of students showing the Reliability of lecturers in giving lectures to students have an influence on student satisfaction. On the other hand, physical evidence in the form of existing facilities on the campus of Islamic Economics College Ihya Ulumiddin today should be improved so that it can increase student satisfaction. 
The results of this study may not be considered as the main reference, but the results of this study can be used as a reference for further research.

The results of the interpretation can be suggested as follows: (1) Improving existing facilities at Islamic Economics College Ihya 'Ulumiddin Banyuwangi so that they can be improved so that lecture facilities can be carried out better. (2) The management of Islamic Economics College Ihya 'Ulumiddin Banyuwangi can carry out activities for students to further enhance relations with students. (3) The management of Islamic Economics College Ihya 'Ulumiddin Banyuwangi can further increase its Reliability to its lecturers by providing opportunities to further improve their competencies so that student satisfaction can be increased. (4) The status of campus accreditation in the future should be a necessity for Islamic Economics College Ihya 'Ulumiddin Banyuwangi so that students can be more confident in their choice to study here. (5) Several factors outside the research variables include individual factors, environmental factors and marketing stimuli. This is in line with Widagdo's (2014) statement which states that consumer decisions in choosing products or services are influenced by 3 factors, namely: (a) individual factors, such as goals, brand characteristics, and individual personality characteristics, (b) factors environment, this context states that the behavior of choosing consumers is also influenced by the surrounding environment and social interaction, and (c) marketing stimuli such as advertising and the like".

\section{Reference}

Abrar, 2009, Pengaruh Kualitas Pelayanan terhadap Kepuasan Mahasiswa Universitas Negeri Padang, TINGKAP Vol. VII No. 2 Th. 2011, di download pada Tanggal 19 Agustus 2018, Jam 16.02.

Alma, Buchari, 2013, Manajemen Pemasaran dan Pemasaran Jasa, Bandung, Penerbit Alfabeta.

Apriliana, Bayu, Fita, Aris; Santoso, Sigit; Sumaryati, Sri, 2014, Pengaruh Kualitas Pelayanan Akademik terhadap Kepuasan Mahasiswa BKK Pendidikan Akuntansi Program Studi Pendidikan Ekonomi Fakultas Keguruan dan Ilmu Pendidikan Universitas Sebelas Maret Surakarta, Jupe UNS, Vol 2, No 3, Hal 211 s/d 223, di download pada Tanggal 19 Agustus 2018, Jam 12.40.

Hadi, Ayik, Rifai, 2012, Pengaruh Kualitas Pelayanan Terhadap Kepuasan Konsumen Pada Kantor Pos Gladag Di Surakarta, Artikel Publikasi Universitas Muhammadiyah Surakarta, di download pada Tanggal 19 Agustus 2018, Jam 13.20.

Firdaus, Moh ; Agustin ; Saleh, Fauzi ; 2004 ; Analisis Penentuan Strategi Mempertahankan Pelanggan/Mahasiswa STE Mandala Jember, STIE Mandala Jember.

Santoso, Fuji; H. Rois Arifin, H.Rois; Slamet,Rachmat, Afi, 2016, Pengaruh Kualitas Pelayanan Dan Fasilitas Terhadap Kepuasan Mahasiswa Fakultas Ekonomi Angkatan 2014-2016 Universitas Islam Malang, e - Jurnal Riset Manajemen PRODI MANAJEMEN Fakultas Ekonomi Unisma. di download pada Tanggal 19 Agustus 2018, Jam 13.45.

Susanto, Hary, 2014, Pengaruh Layanan Akademik Terhadap Kepuasan Mahasiswa Program Pascasarjana Universitas Terbuka Pada Unit Program Belajar Jarak Jauh (Upbjj) Mataram, Jurnal Pendidikan Terbuka dan Jarak Jauh, Volume 15, Nomor 2, September 2014, 88-98, di download pada Tanggal 19 Agustus 2018, Jam 11.50.

Kemenristek Dikti, Undang-Undang No 12 Tahun 2012 tentang Pendidikan Tinggi.

Kotler, Philip; Keller, Kevin, Lane, 2017, Manajemen Pemasaran, Jakarta, Penerbit Erlangga

Mariska, Lidya; Hati, Wahyu, Shinta, 2015, Pengaruh Kualitas Pelayanan Akademik Terhadap Kepuasan Mahasiswa di Politeknik Negeri Batam, Jurnal Akuntansi, Ekonomi dan Manajemen Bisnis vol. 3, no. 1, 2015, 1-9. Di download pada Tanggal 19 Agustus 12.55.

Rahareng, Jennifer, Vinny; Relawan, Nurnida, 2017, Pengaruh Kualitas Pelayanan Akademik Terhadap Kepuasan Mahasiswa (Studi pada Mahasiswa Administrasi Bisnis Universitas Telkom), Jurnal AdBispreneur Vol. 2, No. 2, Agustus 2017 Hal. 125-133.

Sugiyono, 2016, Metode Penelitian, Bandung, Penerbit Alfabeta. 
Sugiarta, I Putu ; Widagda, IGN Jaya Agung, 2013, Pengaruh Kualitas Pelayanan Terhadap Kepuasan Konsumen Pada Warung Subak Denpasar. E-Jurnal Manajemen Universitas Udayana Bali, di download Tgl 21 Oktober 2018 Jam 21.35

Tjiptono, Fandy, 1996, Strategi Bisnis dan Manajemen, Yogyakarta: Penerbit Andi.

Taman, Abdullah; Sukirno; Sari, Ratna, Annisa; Setiawan, Ngadirin ; Pustikaningsih, Adeng, 2013, Analisis Kualitas Pelayanan Terhadap Kepuasan Mahasiswa Pada Fakultas Ekonomi Universitas Negeri Yogyakarta, Jurnal Nominal Volume II/ Nomor I / Tahun 2013, di download pada Tanggal 19 Agustus 2018, Jam 12.30.

Widagdo, Suwignyo, Armanu, Noermijati, and Rofiaty. 2014. "Effect of Political Marketing Mix on Constituents Behavior in Selecting Candidates and Political Parties: Theoretical Studies in Legislative Elections". International Journal of Business and Management Invention 3:47-54.

Widodo, Hendro, 2014, Analisis Kualitas Pelayanan Terhadap Kepuasan Mahasiswa Program Studi Pendidikan Guru Sekolah Dasar, Jurnal PGSD Prodi UAD Universitas Ahmad Dahlan Yogyakarta, di download pada Tanggal 19 Agustus 2018, Jam 12.40 